\title{
Ewa Koniuszewska*
}

\section{OBYWATELSKA INICJATYWA UCHWALODAWCZA}

\section{Streszczenie}

Nowelizacja samorządowych ustaw ustrojowych, dokonana w styczniu 2018 roku, poszerzyła katalog prawnych instrumentów partycypacji mieszkańców jednostek samorządu terytorialnego w rozwiązywaniu rzeczywistych problemów ich wspólnot samorządowych. Katalog ten objął obywatelską inicjatywę uchwałodawczą, którą można kwalifikować jako środek integrujący członków danej społeczności oraz angażujący ich w proces stanowienia prawa. Do czasu wejścia w życie rozwiązań prawnych, wprowadzonych ustawą nowelizującą, problematyka inicjatywy uchwałodawczej stanowiła przedmiot regulacji statutowych. Zakres tych uregulowań był zróżnicowany, dlatego też ustawodawca zdecydował się na ich ujednolicenie.

W niniejszym opracowaniu poddano analizie obowiązujące rozwiązania prawne kształtujące instytucję obywatelskiej inicjatywy uchwałodawczej, a następnie dokonano ich oceny oraz podjęto próbę sformułowania wniosków de lege lata.

Słowa kluczowe: partycypacja, inicjatywa uchwałodawcza, procedura uchwałodawcza

* dr Ewa Koniuszewska, Instytut Nauk Prawnych, Wydział Prawa i Administracji Uniwersytetu Szczecińskiego, adres e-mail: ewa.koniuszewska@usz.edu.pl. ORCID 0000-0003-3993-4524 


\section{Wprowadzenie}

Katalog prawnych instrumentów udziału mieszkańców jednostek samorządu terytorialnego $\mathrm{w}$ identyfikowaniu i rozwiązywaniu rzeczywistych problemów wspólnot samorządowych obejmuje zróżnicowane i w niejednakowym stopniu normatywnie zdeterminowane formy partycypacji. Jedną z form partycypacji społecznej, ale także środkiem integrującym członków danej wspólnoty, jest obywatelska inicjatywa uchwałodawcza. Pojęcie ,inicjatywy uchwałodawczej” nie zostało zdefiniowane przez ustawodawcę. W literaturze przedmiotu wskazuje się na możliwość jego definiowania w sposób analogiczny do tego, w jaki określono pojęcie „inicjatywy ustawodawczej”", z uwagi na istotne podobieństwa między obiema instytucjami ${ }^{2}$. Inicjatywa ustawodawcza ujmowana jest jako prawo przedkładania organowi uprawnionemu do uchwalania ustaw projektów ustaw z określonym skutkiem prawnym w postaci obowiązku poddania tak wniesionego projektu pod jego obrady ${ }^{3}$. W piśmiennictwie zwraca się uwagę, że może ona przybrać postać inicjatywy bezpośredniej i pośredniej. W pierwszym przypadku projekt ustawy poddawany jest pod głosowanie, w którym obywatele decydują o jego przyjęciu lub odrzuceniu. Inicjatywa pośrednia natomiast polega na pozbawieniu obywateli, po przedłożeniu projektu ustawy właściwemu organowi, bezpośredniego wpływu na przyjęcie ustawy, ponieważ ostateczna decyzja w tym zakresie należy do organu przedstawicielskiego ${ }^{4}$. Prawo realizacji obywatelskiej inicjatywy ustawodawczej zagwarantowane zostało na poziomie konstytucyjnym. Na mocy postanowień art. 118 ust. 2 Konstytucji RP ${ }^{5}$ przysługuje ono grupie co najmniej 100 tysięcy obywateli mających prawo wybierania do Sejmu.

1 A. Szewc, T. Szewc, Uchwałodawcza działalność organów samorzadu terytorialnego, Warszawa 1999, s. 58.

2 B. Dolnicki, Obywatelska inicjatywa uchwałodawcza jako forma partycypacji obywateli w podejmowaniu rozstrzygnięć na poziomie lokalnym, w: Partycypacja obywateli i podmiotów obywatelskich $w$ podejmowaniu rozstrzygnięć publicznych na poziomie lokalnym, red. M. Stec, M. Mączyński, Warszawa 2012, s. 114.

3 P. Uziębło, Inicjatywa ustawodawcza obywateli. Ustawa z dnia 24 czerwca 1999 r. z komentarzem, Warszawa 2008, s. 45-46.

4 M. Borski, Inicjatywa ludowa instrumentem presji na ustawodawcę?, „Przegląd Prawa Publicznego" 2016, nr 7-8, s. 56.

5 Konstytucja Rzeczypospolitej Polskiej z 2 kwietnia 1997 r., Dz.U. nr 78, poz. 483 ze zm. 
Tryb postępowania w sprawie wykonywania inicjatywy ustawodawczej przez obywateli określa ustawa z 24 czerwca 1999 roku' .

Odnosząc zatem pojęcie inicjatywy ustawodawczej do warunków oraz struktur lokalnych i regionalnych, należy przyjąć, że inicjatywa uchwałodawcza oznacza uprawnienie określonego podmiotu przedłożenia projektu uchwały organowi stanowiącemu i kontrolnemu lub organowi wykonawczemu? Inicjatywę uchwałodawczą ujmować można jako czynnik inicjujący procedurę uchwałodawczą przed organem stanowiącym i kontrolnym jednostki samorządu terytorialnego. Na wstępnym etapie tej procedury uprawnione (a niekiedy zobowiązane) podmioty przedkładają organowi stanowiącemu propozycje normatywnego uregulowania określonych materii w postaci projektów aktów normatywnych wraz z symulacją finansową skutków ich uchwalenia, z jednoczesnym zobowiązaniem organu stanowiącego do rozpatrzenia tych projektów ${ }^{8}$. W piśmiennictwie zwraca się uwagę, że inicjatywa uchwałodawcza może być postrzegana jako instytucja reglamentująca dostęp do procesu tworzenia prawa. Ograniczenie kręgu podmiotów mogących wystąpić z projektem uchwały nie jest jednak ograniczeniem praw poszczególnych członków danej społeczności, lecz ma na celu zapewnienie właściwego poziomu merytorycznego i legislacyjnego tworzonego prawa ${ }^{9}$.

Należy zwrócić uwagę na potrzebę rozróżniania pojęć: „inicjatywa uchwałodawcza” oraz „przygotowanie projektu uchwały”. Przygotowanie projektu uchwały rozumiane jest jako zespół czynności i działań ukierunkowanych na opracowanie pisemnego dokumentu wyrażającego treść zamierzonego rozstrzygnięcia, odpowiedniego pod względem treści i formy, aby stał się przedmiotem obrad organu samorządowego i przybrał postać uchwały tego organu ${ }^{10}$. Jego zakres znaczeniowy powinien więc obejmować czynności mające na celu realizację wszelkich formalnych wymogów poprzedzających wniesienie projektu uchwały pod obrady organu stanowiącego. Do czynności tych można na przy-

6 Ustawa z 24 czerwca 1999 r. o wykonywaniu inicjatywy ustawodawczej przez obywateli, tekst jedn. Dz.U. z 2018 r., poz. 2120.

7 A. Szewc, T. Szewc, op.cit., s. 58.

8 A. Wierzbica, Referendum i wybory oraz zarzadzenia i uchwaty jednostek samorzadu terytorialnego, Warszawa 2014, s. 358.

9 J. Czerw, Procedury podejmowania uchwat przez rade gminy i powiatu. Poradnik dla praktyków, Warszawa 2010, s. 65.

10 A. Szewc, T. Szewc, op.cit., s. 67. 
kład zaliczyć: właściwe skonstruowanie formy i treści projektu, zapewnienie mu wymaganych prawem opinii ${ }^{11}$.

\section{Zakres podmiotowy i przedmiotowy obywatelskiej inicjatywy uchwałodawczej}

Podstawy prawne obywatelskiej inicjatywy uchwałodawczej ukształtowane zostały na poziomie ustawowym postanowieniami ustawy z 11 stycznia 2018 roku zmianie niektórych ustaw w celu zwiększenia udziału obywateli w procesie wybierania, funkcjonowania i kontrolowania niektórych organów publicznych $^{12}$. Przywołany akt prawny znowelizował samorządowe ustawy ustrojowe ${ }^{13}$, wprowadzając uregulowania mające na celu zwiększenie udziału obywateli w procesie wybierania, kontrolowania oraz funkcjonowania organów jednostek samorządu terytorialnego. Przyjęte rozwiązania prawne ustanowiły nowe instytucje, do których zakwalifikować należy między innymi obywatelską inicjatywę uchwałodawczą. Do czasu wejścia w życie ustawy nowelizującej problematyka obywatelskiej inicjatywy uchwałodawczej stanowiła przedmiot regulacji statutowych. Ujmowana jednak była w statutach relatywnie rzadko i w zróżnicowany sposób ${ }^{14}$. W aktualnym stanie prawnym w każdej z samorządowych ustaw ustrojowych zawarte są uregulowania kształtujące jednolicie instytucję obywatelskiej inicjatywy uchwałodawczej na poziomie lokalnych i regionalnych wspólnot samorządowych.

11 D. Dąbek, Prawo miejscowe, Warszawa 2007, s. 210.

12 Ustawa z 11 stycznia 2018 r. o zmianie niektórych ustaw w celu zwiększenia udziału obywateli w procesie wybierania, funkcjonowania i kontrolowania niektórych organów publicznych, Dz.U. z 2018 r., poz. 130.

13 Ustawa z 8 marca 1990 r. o samorządzie gminnym, tekst jedn. Dz.U. z 2019 r., poz. 506 ze zm., przywoływana dalej jako u.s.g.; ustawa z 5 czerwca 1998 r. o samorządzie powiatowym, tekst jedn. Dz.U. z 2019 r., poz. 511 ze zm., przywoływana dalej jako u.s.p.; ustawa z 5 czerwca 1998 r. o samorządzie województwa, tekst jedn. Dz.U. z 2019 r., poz. 512 ze zm., przywoływana dalej jako u.s.w.

14 Inicjatywa uchwałodawcza przeważnie przysługiwała grupie mieszkańców, której wielkość uzależniona była od liczby mieszkańców danej wspólnoty samorządowej, a prawo inicjatywy uchwałodawczej skorelowane było z wymogiem wpisu mieszkańca do stałego rejestru wyborców; E. Koniuszewska, Inicjatywa uchwałodawcza członków wspólnoty samorzadowej jako narzędzie partycypacji społecznej, w: Partycypacja społeczna w samorządzie terytorialnym, red. B. Dolnicki, Warszawa 2014, s. 418-430. 
Zgodnie z wolą ustawodawcy z obywatelską inicjatywą uchwałodawczą może wystąpić grupa mieszkańców danej jednostki samorządu terytorialnego, posiadających czynne prawa wyborcze do organu stanowiącego ${ }^{15}$. Zakresem podmiotowym regulacji objęto zatem ogół osób fizycznych mających miejsce zamieszkania na obszarze konkretnej wspólnoty samorządowej ${ }^{16}$. Zgodnie $\mathrm{z}$ art. 25 kodeksu cywilnego ${ }^{17}$ miejscem zamieszkania osoby fizycznej jest miejscowość, w której osoba ta przebywa z zamiarem stałego pobytu. Przy tym stałego zamieszkania osoby w określonym miejscu nie ocenia się wyłącznie według jej zameldowania na pobyt stały, lecz na podstawie faktów świadczących o jej stałym przebywaniu w tej miejscowości. Wobec tego zameldowanie na pobyt stały powinno być traktowane jedynie jako jeden z dowodów wskazujących na przebywanie danej osoby na terenie gminy z zamiarem stałego pobytu ${ }^{18}$.

Mieszkańcy jednostki samorządu terytorialnego zamierzając czynić użytek z przyznanego im prawa, muszą legitymować się czynnym prawem wyborczym do organu stanowiącego. W myśl postanowień art. $10 \S 1$ pkt 3 kodeksu wyborczego ${ }^{19}$ prawo wybierania w wyborach do rady gminy ma obywatel polski oraz obywatel Unii Europejskiej niebędący obywatelem polskim, który najpóźniej w dniu głosowania kończy 18 lat oraz stale zamieszkuje na obszarze tej gminy. Z kolei prawo wybierania w wyborach do rady powiatu i sejmiku województwa obywatel polski, który najpóźniej w dniu głosowania kończy 18 lat oraz stale zamieszkuje na obszarze, odpowiednio, tego powiatu i województwa. Jednocześnie, zgodnie z art. $10 \S 2$ kodeksu wyborczego, nie ma prawa wybierania osoba: pozbawiona praw publicznych prawomocnym orzeczeniem sądu, pozbawiona praw wyborczych prawomocnym orzeczeniem Trybunału Stanu, ubezwłasnowolniona prawomocnym orzeczeniem sądu. W piśmiennictwie ograniczenie obywatelskiej inicjatywy uchwałodawczej wyłącznie do mieszkańców wspólnoty mających czynne prawo wyborcze do organu stanowiącego poddawane jest krytyce. Wskazuje się, że niezrozumiała jest rezygnacja z włączenia

15 Art. 41a ust. 1 u.s.g., art. 42a ust. 1 u.s.p., art. 89a ust. 1 u.s.w.

16 A. Szewc, Komentarz do art. 1, w: A. Szewc, G. Jyż, Z. Pławecki, Ustawa o samorzadzie gminnym. Komentarz, Warszawa 2012, s. 34.

17 Ustawa z 23 kwietnia 1964 r. Kodeks cywilny, tekst jedn. Dz.U. z 2019 r., poz. 1145.

18 B. Dolnicki, Komentarz do art. 1, w: Ustawa o samorzadzie gminnym. Komentarz, red. B. Dolnicki, Warszawa 2016, s. 25-26.

19 Ustawa z 5 stycznia 2011 r. Kodeks wyborczy, tekst jedn. Dz.U. z 2019 r., poz. 684 ze zm. 
w sprawy publiczne niepełnoletnich mieszkańców, podczas gdy te same osoby mogą składać skargi, wnioski i petycje ${ }^{20}$. Możliwość przyznania niepełnoletnim członkom wspólnoty samorządowej prawa występowania z inicjatywą uchwałodawczą należałoby rozpatrywać również w kontekście funkcjonowania na poziomie gminy młodzieżowej rady gminy. Stosownie do postanowień art. $5 \mathrm{~b}$ ust. 2 u.s.g. rada gminy na wniosek zainteresowanych środowisk może wyrazić zgodę na utworzenie młodzieżowej rady gminy mającej charakter konsultacyjny. Organ ten ma możliwość oddziaływania na życie publiczne społeczności lokalnej m.in. przez: reprezentowanie interesów młodzieży przed organami samorządu gminnego, władzami oświatowymi, organizacjami pozarządowymi; podejmowanie działań na rzecz integracji i współpracy środowisk młodzieżowych, inicjowanie przedsięwzięć dotyczących młodzieży, zwłaszcza w zakresie nauki, kultury i sportu. Do zadań młodzieżowej rady gminy może także należeć opiniowanie projektów niektórych uchwał, w szczególności wywierających wpływ na warunki rozwoju młodego pokolenia ${ }^{21}$, oraz występowanie do przewodniczącego rady, radych i organu wykonawczego o podjęcie inicjatywy uchwałodawczej ${ }^{22}$. Wobec dopuszczalności podejmowania przez młodzieżową radę gminy czynności bezpośrednio związanych z procesem uchwałodawczym zasadne byłoby włączenie niepełnoletnich mieszkańców gminy do grona podmiotów uprawnionych do wystąpienia z obywatelską inicjatywą uchwałodawczą. Przypuszczać jednak należy, że ustawodawca statuując prawo obywatelskiej inicjatywy uchwałodawczej, posiłkował się rozwiązaniami prawnymi zawartymi w ustawie o wykonywaniu inicjatywy ustawodawczej przez obywateli. Akt ten także uzależnia realizację prawa inicjatywy ustawodawczej od posiadania prawa wybierania do Sejmu.

Warunkiem realizacji przez członków wspólnot samorządowych prawa inicjatywy uchwałodawczej jest działanie w sposób zorganizowany. W tym celu tworzą oni grupę osób popierającą inicjatywę, a wielkość tej grupy uzależniona jest od liczby mieszkańców danej jednostki samorządu terytorialnego. Na poziomie gminy grupa ta musi liczyć: co najmniej 100 osób - w gminie do 5000 mieszkańców, co najmniej 200 osób - w gminie do 20000 mieszkańców, co najmniej

20 P. Kłucińska, D. Sześciło, B. Wilk, Nowy model demokracji samorządowej-uwagi na tle zmian w ustawach samorzadowych wprowadzonych ustawa z 11 stycznia 2018 r., „Samorząd Terytorialny" 2018, nr 10, s. 34.

21 M. Mączyński, Komentarz do art. 5b, w: Ustawa o samorządzie gminnym. Komentarz, red. P. Chmielnicki, Warszawa 2013, s. 141.

22 Statut Młodzieżowej Rady Miejskiej w Łodzi, https://uml.lodz.pl/files/public/dla_mieszkanca/Statut_ujednolicony_MRM_pdf.pdf (dostęp 25.10.1019). 
300 osób - w gminie powyżej 20000 mieszkańców. W powiecie wielkość tej grupy wynosi: co najmniej 300 osób - w powiecie do 100000 mieszkańców, co najmniej 500 osób - w powiecie powyżej 100000 mieszkańców. Natomiast na poziomie województwa samorządowego grupa mieszkańców występująca z inicjatywą uchwałodawczą musi liczyć co najmniej 1000 osób. Przyjęte przez ustawodawcę progi poparcia projektu uchwały w najmniejszych wspólnotach samorządowych są zbyt wysokie, jeśli uwzględni się niski stopień społecznego zaangażowania w sprawy lokalne ${ }^{23}$. Zauważyć należy, że przedstawiciele nauki sygnalizowali, już na etapie prac nad projektem ustawy wprowadzającej obywatelską inicjatywę uchwałodawczą, niebezpieczeństwo związane z ustanowieniem zbyt wysokiej liczby osób wymaganej do poparcia projektu uchwały. Wskazywano, że ustalenie liczby koniecznych podpisów powinno opierać się na obiektywnym kryterium. Proponowano, aby za układ odniesienia służyła wymagana liczba podpisów do wniesienia inicjatywy ustawodawczej ${ }^{24}$. Ponadto podkreślano, że próg poparcia powinien być ustalany w sposób, który w odczuciu danej społeczności zachęci do wnoszenia projektów. Natomiast z drugiej strony ma on być jednocześnie realną barierą przed podejmowaniem pochopnych inicjatyw uchwałodawczych ${ }^{25}$.

Ustawodawca formułując wymóg poparcia inicjatywy uchwałodawczej, posłużył się sformułowaniem „grupa mieszkańców”. Rozważyć zatem należy, czy poparcia powinna udzielić grupa mieszkańców wyodrębniona spośród ogółu mieszkańców danej jednostki samorządu terytorialnego, czy też grupa obejmująca wyłącznie osoby posiadające czynne prawo wyborcze do organu stanowiącego. Użyte w ust. 2 art. 41a u.s.g. (odpowiednio ust. 2 art. 42a u.s.p., ust. 2 art. 89a u.s.w.) odesłanie do ust. 1, określającego prawo grupy mieszkańców posiadających czynne prawo wyborcze do organu stanowiącego, uzasadnia twierdzenie, że tylko grupa obejmująca mieszkańców mających legitymację czynną może skutecznie popierać inicjatywę uchwałodawczą. Jednocześnie zaznaczyć należy, że ustawodawca ustalając w art. 28aa ust. 7 u.s.g. (odpowiednio art. 30a ust. 7 u.s.p. i art. 34a ust. 7 u.s.w.) warunki udziału mieszkańców jednostki

23 R. Marchaj, Komentarz do art. 41a, w: Ustawa o samorzadzie gminnym. Komentarz, red. B. Dolnicki, wyd. II, WKP 2018, LEX/el.

24 B. Dolnicki, Obywatelska inicjatywa uchwałodawcza..., s. 128.

25 M. Augustyniak, Inicjatywa uchwałodawcza mieszkańców jako forma partycypacji spotecznej $w$ jednostkach samorzadu terytorialnego - wnioski de lege lata i postulaty de lege ferenda, w: Partycypacja spoteczna..., s. 368. 
samorządu terytorialnego w debacie nad raportem o jej stanie nie wymaga, aby pisemne zgłoszenie zabrania głosu $\mathrm{w}$ debacie poparte zostało podpisami mieszkańców mających czynne prawo wyborcze do organu stanowiącego. Wymóg legitymowania się czynnym prawem wyborczym nie został również sformułowany w odniesieniu do mieszkańców popierających projekt realizowany w ramach budżetu obywatelskiego. Przywołane regulacje prawne uwidaczniają stosowanie zróżnicowanych kryteriów warunkujących udział członków wspólnoty samorządowej w przedsięwzięciach jej dotyczących.

Uregulowania kształtujące wymóg udzielenia poparcia inicjatywie uchwałodawczej nie zawierają postanowień wykluczających możliwość cofnięcia udzielonego poparcia ${ }^{26}$. Ustawodawca nie zdecydował się na przyjęcie rozwiązania będącego odpowiednikiem art. 9 ust. 3 ustawy o wykonywaniu inicjatywy ustawodawczej przez obywateli, zgodnie z którym wycofanie poparcia udzielonego projektowi ustawy jest nieskuteczne. Brak analogicznej regulacji odnoszącej się do inicjatywy uchwałodawczej stwarza ryzyko wystąpienia sytuacji, w której niezbędne będzie uzupełnianie udzielonego poparcia bezpośrednio przed złożeniem projektu uchwały organowi stanowiącemu.

Zakres przedmiotowy obywatelskiej inicjatywy uchwałodawczej objął sprawy mieszczące się w ramach zadań i kompetencji organów stanowiących i kontrolnych jednostek samorządu terytorialnego. Konieczne jest jednak wyłączenie z tego zakresu spraw, w których z mocy przepisu szczególnego inicjatywa uchwałodawcza zastrzeżona została na rzecz konkretnych podmiotów. Ustawodawca bowiem w niektórych obszarach powierzył inicjatywę uchwałodawczą: wójtowi, zainteresowanym środowiskom, komisji rewizyjnej, określonej liczbie radnych $^{27}$. Wobec braku innych ograniczeń sądzić należy, że przedmiotem inicjatywy uchwałodawczej mogą być projekty uchwał mające stać się aktami prawa miejscowego, jak również takie, które nie będą miały charakteru powszechnie obowiązującego.

26 R. Marchaj, op.cit.

27 Zob. J. Czerw, Stanowienie uchwat przez rade gminy, „Samorząd Terytorialny” 2015, nr 12, s. 35; J. Czerw, Procedury podejmowania ..., s. 65-67. 


\section{Postępowanie z projektem obywatelskim}

Stosownie do postanowień art. 41a ust. 3 u.s.g. (odpowiednio art. 42a ust. 3 u.s.p. i art. 89 a ust. 3 u.s.w.) projekt uchwały zgłoszony w ramach obywatelskiej inicjatywy uchwałodawczej staje się przedmiotem obrad rady gminy na najbliższej sesji po złożeniu projektu, jednak nie później niż po upływie 3 miesięcy od dnia złożenia projektu. $Z$ treści przywołanego rozwiązania prawnego można wyinterpretować obowiązki spoczywające na inicjatorze postępowania uchwałodawczego oraz na organie właściwym do przeprowadzenia tego postępowania. Inicjująca postępowanie uchwałodawcze grupa mieszkańców jednostki, realizując zagwarantowane jej prawo, zobligowana jest do przedłożenia projektu uchwały. W orzecznictwie podkreśla się, że w ramach obywatelskiej inicjatywy uchwałodawczej członkowie wspólnot samorządowych mają prawo do opracowania oraz złożenia projektu uchwały, który z mocy prawa, po spełnieniu warunków formalnych, powinien stać się przedmiotem obrad, a następnie zostać poddany pod głosowanie organu stanowiącego ${ }^{28}$. Przedmiotem inicjatywy uchwałodawczej jest zatem projekt uchwały, a więc projekt w postaci, która pozwala na dołączenie go przez przewodniczącego organu stanowiącego do porządku obrad. Wobec powyższego nie będzie można uznać za realizację inicjatywy uchwałodawczej przedłożonych założeń do projektu uchwały. Zgłoszone bowiem postulaty uregulowania problemu czy też wskazany przez wnioskodawców kierunek pożądanych działań będą musiały dopiero zostać ujęte w ramy projektu uchwały przygotowanego przez organ wykonawczy ${ }^{29}$. Odwołując się do uregulowań dotyczących obywatelskiej inicjatywy ustawodawczej, które nadały jej kształt tak zwanej inicjatywy „sformułowanej”30, stwierdzić można, że na gruncie obowiązujących rozwiązań prawnych obywatelska inicjatywa uchwałodawcza przybrała analogiczną postać. Inicjatywa „sformułowana” oznacza konieczność przedkładania propozycji zgodnie z zasadami techniki prawodawczej i jest przeciwstawiana inicjatywie ,niesformułowanej”, której istotą jest traktowanie inicjatywy ustawodawczej jako postulatu ${ }^{31}$.

28 Rozstrzygnięcie nadzorcze nr NPII.4131.1.656.2018 Wojewody Śląskiego z 14 grudnia 2018 r., Dz. Urz. Woj. Śląskiego z 2018 r., poz. 8074.

29 Wyrok WSA z 25 czerwca 2019 r., III SA/G1 435/19, LEX nr 2706767.

30 Art. 118 ust. 3 Konstytucji RP.

31 A. Szmyt, Obywatelska inicjatywa ustawodawcza, „Gdańskie Studia Prawnicze” 1998, t. III, s. 151-152. 
Mając na uwadze poczynione uprzednio ustalenia terminologiczne i potrzebę delimitacji pojęć: ,inicjatywa uchwałodawcza” oraz „przygotowanie projektu uchwały”, przyjąć należy, że prawo mieszkańców jednostki samorządu terytorialnego do wystąpienia $\mathrm{z}$ inicjatywą uchwałodawczą skorelowane jest z obowiązkiem przygotowania projektu uchwały. Konieczność przygotowania przez wnioskodawcę projektu uchwały uzasadniają w istocie względy praktyczne. Skierowanie projektu uchwały pod obrady organu stanowiącego musi być poprzedzone uzyskaniem poparcia określonej grupy mieszkańców, którzy powinni zapoznać się z jego treścią. $\mathrm{W}$ przeciwnym wypadku projekt uchwały sporządzony po zebraniu wymaganej liczby podpisów członków wspólnoty samorządowej mógłby nie spełniać oczekiwań osób opierających inicjatywę, a nawet być niezgodny $z$ ich intencją ${ }^{32}$.

Przygotowany w ramach obywatelskiej inicjatywy uchwałodawczej projekt uchwały powinien odpowiadać wymaganiom stawianym projektom wnoszonym przez pozostałe podmioty, którym przysługuje inicjatywa uchwałodawcza. W literaturze przedmiotu wskazuje się, że wymogi określone w „Zasadach techniki prawodawczej”"33 należy stosować do uchwał organów stanowiących jednostek samorządu terytorialnego będących aktami prawa miejscowego. Pożądane jest jednak, aby jednolita konstrukcja i forma stosowane były wobec wszystkich uchwał podejmowanych przez organy stanowiące wspólnot samorządowych. Uchwały powinny być zbudowane według schematu obejmującego: tytuł, podstawę prawną, przepisy merytoryczne - ogólne i szczegółowe, w zależności od potrzeb przepisy przejściowe lub dostosowujące, przepisy końcowe, podpis uchwały $^{34}$. Zaznaczyć należy, że postanowienia art. 58 ust. 1 u.s.g. w odniesieniu do uchwał organów gminy dotyczących zobowiązań finansowych statuują obowiązek wskazania źródeł, z których zobowiązania te zostaną pokryte. Przywołana regulacja prawna jest źródłem wątpliwości interpretacyjnych i poddawana jest przez przedstawicieli doktryny krytyce ${ }^{35}$. Zwraca się uwagę, że nie

32 Wyrok WSA z 25 czerwca 2019 r., III SA/G1 435/19, LEX nr 2706767.

33 § 143 załącznika do Rozporządzenia Prezesa Rady Ministrów z 20 czerwca 2002 r. w sprawie „Zasad techniki prawodawczej”, tekst jedn. Dz.U. z 2016 r., poz. 283.

34 J. Czerw, I. Krześnicki, Działalność uchwałodawcza rady gminy ze wzorami uchwat, procedur i pism, Warszawa 2007, s. 161-162.

35 P. Kryczko, Komentarz do art. 58, w: Ustawa o samorzadzie gminnym. Komentarz, red. P. Chmielnicki, Warszawa 2013, s. 756-760. 
koresponduje ona $\mathrm{z}$ uregulowaniami ustawy o finansach publicznych ${ }^{36}$, a wymóg wskazania źródła, z których zobowiązania zostaną pokryte, jest nielogiczny i niewykonalny ${ }^{37}$. Mimo ujemnej oceny postanowień art. 58 ust. 1 u.s.g. mogą być one traktowane jako źródło obowiązku adresowanego do mieszkańców gminy realizujących prawo inicjatywy uchwałodawczej. Nasuwa się w związku z tym pytanie o realną możliwość wskazania przez inicjatorów postępowania uchwałodawczego, na etapie przygotowania projektu uchwały, źródeł pokrycia zobowiązań finansowych. Spodziewać się należy, że kategoryczne przestrzeganie wykonania tego obowiązku będzie skutkować osłabieniem woli mieszkańców uczestnictwa w inicjowaniu procedury uchwałodawczej, a w rezultacie ograniczeniem ich aktywności.

Z istoty obywatelskiej inicjatywy uchwałodawczej wynikają obowiązki nie tylko dla mieszkańców jednostek samorządu terytorialnego, ale także dla organów stanowiących wspólnot samorządowych. Rada oraz sejmik zobligowane są do rozpatrzenia przedłożonego projektu uchwały $\mathrm{w}$ ramach procedury uchwałodawczej. Zgodnie z uregulowaniami samorządowych ustaw ustrojowych projekt uchwały staje się przedmiotem obrad organu stanowiącego na najbliższej sesji po złożeniu projektu, jednak nie później niż po upływie 3 miesięcy od dnia złożenia projektu. Przyjęte rozwiązanie prawne eliminuje możliwość dokonywania przez organ stanowiący zmian w przedłożonym projekcie przed sesją tego organu. Projekt powinien bowiem bezpośrednio trafić pod obrady organu stanowiącego. Natomiast w kolejnych etapach procedury uchwałodawczej rada lub sejmik mają możliwość ingerencji w treść przedłożonego projektu uchwały. Uwzględnienie projektu zgłoszonego przez mieszkańców uzależnione będzie od jego merytorycznego kształtu, ale także od elementów polityki lokalnej, które determinują poparcie bądź odrzucenie określonych rozwiązań, w tym rozwiązań prawnych $^{38}$. Termin dla organu stanowiącego wspólnoty samorządowej do rozpoczęcia procedowania nad projektem określony został ramowo. Jego moment początkowy wyznacza pierwsza sesja odbywająca się po złożeniu projektu, z kolei jego zakończenie następuje z upływem trzeciego miesiąca, licząc od dnia

36 Ustawa z 27 sierpnia 2009 r. o finansach publicznych, tekst jedn. Dz.U. z 2019 r., poz. 869 .

37 J. Glumińska-Pawlic, Komentarz do art. 58, w: Ustawa o samorzadzie gminnym. Komentarz, red. B. Dolnicki, Warszawa 2016, s. 1012-1014.

38 P. Uziębło, Inicjatywa uchwałodawcza mieszkańców gminy, „Gdańskie Studia Prawnicze - Przegląd Orzecznictwa" 2011, nr 2, s. 58. 
złożenia projektu. Ustawodawca nie sprecyzował konsekwencji przekroczenia terminu, jak również skutków bezczynności organu stanowiącego. Za mankament analizowanego rozwiązania prawnego uznać należy pozbawienie mieszkańców występujących z obywatelską inicjatywą uchwałodawczą we wskazanej sytuacji środków ochrony prawnej. Mimo akcentowania przez przedstawicieli nauki potrzeby zagwarantowania inicjatorom projektu wnoszonego przez mieszkańców możliwości złożenia skargi do sądu administracyjnego na bezczynność organu stanowiącego postulat ten nie został uwzględniony ${ }^{39}$.

Zainicjowanie postępowania uchwałodawczego w ramach inicjatywy obywatelskiej oraz jego kontynuacja wymagają wielu czynności, do realizacji których nieodzowne jest zorganizowanie się członków wspólnot samorządowych. Zapewnieniu poprawności podejmowanych działań i zwiększeniu ich efektywności służyć ma utworzenie komitetu inicjatywy uchwałodawczej. Zasady tworzenia komitetów inicjatyw uchwałodawczych powinny zostać określone w uchwale organu stanowiącego. Przy ich precyzowaniu pomocne może być posiłkowanie się rozwiązaniami zawartymi w ustawie o wykonywaniu inicjatywy ustawodawczej przez obywateli, z zastrzeżeniem uwzględniania różnic między inicjatywą ustawodawczą a inicjatywą uchwałodawczą. W piśmiennictwie wskazuje się, że zasady tworzenia, działania i finansowania komitetu obywatelskiej inicjatywy uchwałodawczej nie powinny minimalizować szans na jego zawiązanie ani nadmiernie utrudniać jego funkcjonowania $\mathrm{w}$ praktyce ${ }^{40}$. Zgodnie $\mathrm{z}$ wolą ustawodawcy komitet inicjatywy uchwałodawczej ma prawo wskazywać osoby uprawnione do reprezentowania komitetu podczas prac organu stanowiącego. Wytypowanie konkretnego członka tego komitetu jako jego reprezentanta zasadniczo powinno nastąpić $\mathrm{w}$ formie uchwały tego gremium ${ }^{41}$. W orzecznictwie sądowoadministracyjnym wskazuje się, że organ stanowiący nie ma kompetencji do ustalania zasad reprezentowania komitetu, bowiem takie uprawnienie nie mieści się w upoważnieniu do ,ustalenia szczegółowych zasad wnoszenia inicjatyw obywatelskich"42.

39 W. Kisiel, Udziat jednostki w procedurze uchwałodawczej rady gminy (pytania de lege ferenda), w: Partycypacja obywateli..., s. 105, M. Augustyniak, Inicjatywa uchwałodawcza mieszkańców..., s. 378.

40 D. Ziółkowski, Komentarz do art. 4la, w: Ustawa o samorządzie gminnym. Komentarz, red. S. Gajewski, A. Jakubowski, Legalis (dostęp 25.10.2019).

41 Ibidem.

42 Wyrok WSA z 4 lipca 2019 r. III SA/Gd 333/19, LEX nr 2698392. 
Ustawodawca regulując w samorządowych ustawach ustrojowych instytucję obywatelskiej inicjatywy uchwałodawczej, wytyczył jej ramy. Jednocześnie zobowiązał organy stanowiące wspólnot samorządowych do określenia w drodze uchwały: szczegółowych zasad wnoszenia inicjatyw obywatelskich, zasad tworzenia komitetów inicjatyw uchwałodawczych, zasad promocji obywatelskich inicjatyw uchwałodawczych, formalnych wymogów, jakim muszą odpowiadać składane projekty. Organ stanowiący zobligowany jest do wyczerpania zakresu upoważnienia ustawowego przez uregulowania wszystkich kwestii uznanych przez ustawodawcę za istotne. Niewypełnienie tego obowiązku skutkować będzie stwierdzeniem istotnego naruszenia prawa, a w konsekwencji doprowadzi do uznania nieważności uchwały ${ }^{43}$.

\section{Podsumowanie}

Obywatelska inicjatywa uchwałodawcza uzupełniła katalog ustawowych środków udziału mieszkańców jednostek samorządu terytorialnego w podejmowaniu rozstrzygnięć w sprawach istotnych dla danej społeczności. Należy pozytywnie ocenić przesunięcie regulacji inicjatywy uchwałodawczej z poziomu podustawowego na poziom ustawowy. Za sprawą tego zabiegu legislacyjnego zagwarantowano mieszkańcom wszystkich jednostek samorządu terytorialnego prawo urzeczywistniania inicjatywy uchwałodawczej, a także ujednolicono dotyczące jej zróżnicowane dotychczas rozwiązania prawne. Wprowadzone przez ustawodawcę uregulowania umożliwiły wyszczególnienie głównych elementów analizowanej instytucji, do których należą: zakres podmiotowy, zakres przedmiotowy oraz tryb postępowania.

Kształtując obywatelską inicjatywę uchwałodawczą, ustawodawca posiłkował się rozwiązaniami prawnymi normującymi obywatelską inicjatywę ustawodawczą. Odwoływanie się do tych rozwiązań wymagało uwzględnienia uwarunkowań i specyfiki funkcjonowania wspólnot samorządowych, dlatego też tylko część spośród nich mogła zostać recypowana.

43 Wyrok WSA z 25 czerwca 2019 r., III SA/G1 435/19, LEX nr 2706767. 


\section{Literatura}

Augustyniak M., Inicjatywa uchwałodawcza mieszkańców jako forma partycypacji społecznej w jednostkach samorzadu terytorialnego - wnioski de lege lata i postulaty de lege ferenda, w: Partycypacja społeczna w samorzadzie terytorialnym, red. B. Dolnicki, Warszawa 2014.

Borski M., Inicjatywa ludowa instrumentem presji na ustawodawcę?, „Przegląd Prawa Publicznego" 2016, nr 7-8.

Czerw J., Krześnicki I., Działalność uchwałodawcza rady gminy ze wzorami uchwat, procedur i pism, Warszawa 2007.

Czerw J., Procedury podejmowania uchwat przez rade gminy i powiatu. Poradnik dla praktyków, Warszawa 2010.

Czerw J., Stanowienie uchwał przez rade gminy, „Samorząd Terytorialny” 2015, nr 12.

Dąbek D., Prawo miejscowe, Warszawa 2007.

Dolnicki B., Obywatelska inicjatywa uchwałodawcza jako forma partycypacji obywateli w podejmowaniu rozstrzygnięć na poziomie lokalnym, w: Partycypacja obywateli i podmiotów obywatelskich w podejmowaniu rozstrzygnięć publicznych na poziomie lokalnym, red. M. Stec, M. Mączyński, Warszawa 2012.

Dolnicki B., Komentarz do art. 1, w: Ustawa o samorzadzie gminnym. Komentarz, red. B. Dolnicki, Warszawa 2016.

Kisiel W., Udziat jednostki w procedurze uchwałodawczej rady gminy (pytania de lege ferenda), w: Partycypacja obywateli i podmiotów obywatelskich $w$ podejmowaniu rozstrzygnięć publicznych na poziomie lokalnym, red. M. Stec, M. Mączyński, Warszawa 2012.

Kłucińska P., Sześciło D., Wilk B., Nowy model demokracji samorządowej- uwagi na tle zmian $w$ ustawach samorzadowych wprowadzonych ustawa z 11 stycznia 2018 r., „Samorząd Terytorialny” 2018, nr 10.

Koniuszewska E., Inicjatywa uchwałodawcza członków wspólnoty samorządowej jako narzędzie partycypacji społecznej, w: Partycypacja społeczna $w$ samorzadzie terytorialnym, red. B. Dolnicki, Warszawa 2014.

Kryczko P., Komentarz do art. 58, w: Ustawa o samorzadzie gminnym. Komentarz, red. P. Chmielnicki, Warszawa 2013.

Marchaj R., Komentarz do art. 4la, w: Ustawa o samorzadzie gminnym. Komentarz, red. B. Dolnicki, wyd. II, WKP 2018, LEX/el.

Mączyński M., Komentarz do art. 5b, w: Ustawa o samorzadzie gminnym. Komentarz, red. P. Chmielnicki, Warszawa 2013. 
Szewc A., Szewc T., Uchwałodawcza działalność organów samorzadu terytorialnego, Warszawa 1999.

Szewc A., Komentarz do art. 1, w: A. Szewc, G. Jyż, Z. Pławecki, Ustawa o samorzadzie gminnym. Komentarz, Warszawa 2012.

Szmyt A., Obywatelska inicjatywa ustawodawcza, „Gdańskie Studia Prawnicze” 1998, t. III.

Uziębło P., Inicjatywa ustawodawcza obywateli. Ustawa z dnia 24 czerwca 1999 r. z komentarzem, Warszawa 2008.

Uziębło P., Inicjatywa uchwałodawcza mieszkańców gminy, „Gdańskie Studia Prawnicze - Przegląd Orzecznictwa” 2011, nr 2.

Wierzbica A., Referendum $i$ wybory oraz zarzadzenia $i$ uchwaty jednostek samorzadu terytorialnego, Warszawa 2014.

Ziółkowski D., Komentarz do art. 4la, w: Ustawa o samorzadzie gminnym. Komentarz, red. S. Gajewski, A. Jakubowski, Legalis.

\section{Akty prawne}

Konstytucja Rzeczypospolitej Polskiej z 2 kwietnia 1997 r., Dz.U. nr 78, poz. 483 ze zm. Rozporządzenie Prezesa Rady Ministrów z 20 czerwca 2002 r. w sprawie „Zasad techniki prawodawczej”, tekst jedn. Dz.U. z 2016 r., poz. 283.

Ustawa z 11 stycznia 2018 r. o zmianie niektórych ustaw w celu zwiększenia udziału obywateli w procesie wybierania, funkcjonowania i kontrolowania niektórych organów publicznych, Dz.U. z 2018 r., poz. 130.

Ustawa z 15 września 2000 r. o referendum lokalnym, tekst jedn. Dz.U. z 2019 r., poz. 741.

Ustawa z 23 kwietnia 1964 r. Kodeks cywilny, tekst jedn. Dz.U. z 2019 r., poz. 1145.

Ustawa z 24 czerwca 1999 r. o wykonywaniu inicjatywy ustawodawczej przez obywateli, tekst jedn. Dz.U. z 2018 r., poz. 2120.

Ustawa z 27 sierpnia 2009 r. o finansach publicznych, tekst jedn. Dz.U. z 2019 r., poz. 869.

Ustawa z 5 czerwca 1998 r. o samorządzie powiatowym, tekst jedn. Dz.U. z 2019 r., poz. $511 \mathrm{ze} \mathrm{zm}$.

Ustawa z 5 czerwca 1998 r. o samorządzie województwa, tekst jedn. Dz.U. z 2019 r., poz. 512 ze zm.

Ustawa z 5 stycznia 2011 r. Kodeks wyborczy, tekst jedn. Dz.U. z 2019 r., poz. 684 ze zm.

Ustawa z 8 marca 1990 r. o samorządzie gminnym, tekst jedn. Dz.U. z 2019 r., poz. 506 ze zm. 


\title{
Orzecznictwo
}

Rozstrzygnięcie nadzorcze nr NPII.4131.1.656.2018 Wojewody Śląskiego z 14 grudnia 2018 r., Dz. Urz. Woj. Śląskiego z 2018 r., poz. 8074.

Wyrok WSA z 25 czerwca 2019 r., III SA/Gl 435/19, LEX nr 2706767.

Wyrok WSA z 4 lipca 2019 r., III SA/Gd 333/19, LEX nr 2698392.

\section{Źródla internetowe}

Statut Młodzieżowej Rady Miejskiej w Łodzi, https://uml.lodz.pl/files/public/dla mieszkanca/Statut_ujednolicony_MRM_pdf.pdf.

\section{CITIZENS' RESOLUTION-PASSING INITIATIVE}

\begin{abstract}
Summary
Amendment to local government political acts, introduced in January 2018, expanded the catalogue of legal instruments for participation of residents of local government units in solving the actual problems of their self-governing communities. The catalogue included a citizens' resolution-passing initiative, which may be classified as a means of integrating members of a given community and involving them in the process of law making. Until the entry into force of legal solutions, introduced by the amending act, the issues of the resolution-passing initiative were subject to statutory regulations. The scope of these regulations was diverse, which is why the legislator decided to harmonise them.

The study includes an analysis of applicable legal solutions that shape the institution of the citizens' resolution-passing initiative as well as their assessment and an attempt to formulate de lege lata conclusions.
\end{abstract}

Keywords: participation, resolution-passing initiative, resolution-passing procedure 